\title{
Removal of Heavy Metals from Stormwater Using Porous Concrete Pavement
}

\author{
Kalimur Rahman ${ }^{1}$, Saurav Barua ${ }^{2 *}$, Md. Shibly Anwar ${ }^{1}$, Md. Zakir Hasan $^{1}$, Saiful Islam ${ }^{1}$ \\ ${ }^{1}$ Department of Civil Engineering, Dhaka University of Engineering and Technology, Gazipur, Bangladesh \\ ${ }^{2}$ Department of Civil Engineering, Daffodil International University, Dhaka, Bangladesh \\ * Corresponding author email: saurav.ce@diu.edu.bd
}

Received: 26 May 2020 / Revised: 18 June 2020 / Accepted: 08 July 2020 / Published: 09 July 2020

\section{ABSTRACT}

\begin{abstract}
This study aimed to investigate the heavy metals, i.e. $\mathrm{Cu}, \mathrm{Pb}, \mathrm{Ni}$ and $\mathrm{Zn}$ removal efficiency from stormwater runoff of a porous concrete pavement (PCP). A model of PCP was designed with the porosity and co-efficient of permeability of the pavement were $27.2 \%$ and $1.83 \mathrm{~cm} / \mathrm{sec}$, respectively. Artificial stormwater containing heavy metals are passed through the pavement at a constant rainfall rate to mimic the stormwater rainfall-runoff condition. The artificial stormwater infiltrated through the pavement were then collected at two different pavement layers at different time instances. From the experimental investigations, it is observed that $\mathrm{Cu}, \mathrm{Pb}, \mathrm{Ni}$ and $\mathrm{Zn}$ concentrations are significantly reduced in the treated stormwater. At the first collection point which is located below the sub-base layer and coarse sand layer of the pavement, the concentrations of $\mathrm{Cu}, \mathrm{Pb}$ and $\mathrm{Zn}$ reduced $56 \%, 67 \%$ and $93 \%$ respectively compared to their initial concentration, Ni concentration reduced only $20 \%$. At the second collection point which is located below the coarse and fine sand layers beneath the pavement, the concentrations of $\mathrm{Cu}, \mathrm{Pb}, \mathrm{Zn}$, and $\mathrm{Ni}$ are reduced $92 \%, 89 \%, 100 \%, 100 \%$, respectively.
\end{abstract}

Keywords: Porous concrete pavement, heavy metal removal, stormwater, Pavement layers, artificial rainfall

\section{Introduction}

This study focuses on the Porous concrete pavement (PCP) application to reduce heavy metal contaminated stormwater. PCP is a feasible alternative to reduce stormwater runoff and can remove various heavy metals, such as, $\mathrm{Zn}$ and $\mathrm{Cu}$ significantly [1]. Porous concrete is an opengraded material with zero-slump, comprises with coarse aggregate, cement, water and contains few or no fine aggregates, i.e. sand. It is also known as "no-fines" concrete. PCP usually has interconnected void space of $15 \%-25 \%$ and a surface permeability of 300 to $2000 \mathrm{inch} / \mathrm{h}$ [2]. It captures rainwater by allowing water to seep into the ground, recharges groundwater, reduces stormwater runoff, ensure efficient usage of land and lower overall impervious surfaces. Although the porous concrete has high water permeability and lower compressive strength, lower durability compared to conventional concrete, but it has enough strength for use in parking lots, roof tops and driveways. As a rule of thumb, $150 \mathrm{~mm}$ of Porous concrete pavement can carry the same light traffic that would normally be carried by 100 mm of conventional concrete pavement [3].

Since water quality maintenance and sanitation infrastructure do not cope up with rapid urbanization and population growth, the pollution of heavy metals in water is a major concern in many developing cities. Sources of heavy metals can be natural and artificial. Artificial sources of heavy metal include direct disposal of untreated industrial waste, mining effluent containing heavy metal contamination and runoff of pesticides, fertilizer used in the agricultural fields. Heavy metals can accumulate in human body, non-degradable in nature, resulting in damage to internal organs and nervous system [4]. It is recognized that heavy metal such as $\mathrm{Cu}, \mathrm{Zn}, \mathrm{Pb}$ and $\mathrm{Ni}$ can prevent biological system of ecosystem. 
Removal of Heavy Metals from Stormwater Using Porous Concrete Pavement

A considerable amount of studies have been performed on the removal effectiveness of porous concrete pavement systems for hydrocarbons, nutrients, fecal coliforms, metals, and various contaminants [5-7]. The advantages of PCP systems are reduced runoff, improved water quality, sediment filtering, pollutant removal and increased infiltration of rainfall [8]. Recent studies related to porous concrete pavement includes, application of PCP in Municipal waste treatment [9] and blending Geopolymer with porous concrete to remove heavy metals [10].For environmental ecosystem protection it is essential to removed or reduced heavy metal pollutant. Remove heavy metalcontaminated wastewater pollutant is very difficult and costly. If porous concrete pavement used to remove pollutant the pavement is made by local materials. It made easily and economic and no bad effect on environment.

The aim of the study is to assess the efficiency of Porous concrete pavement (PCP) for removal of heavy metal in stormwater pollutants at different layers. PCP is a viable alternative to reduce stormwater runoff in the urban stormwater management. The study determines the stormwater quality before infiltration and compares the percent removal of heavy metals concentration in stormwater by PCP. The main challenge of this study is to investigate the heavy metal removal efficiency of PCP from stormwater in context of Bangladesh and access its applicability.

\section{Research Methodology}

\subsection{PCP Model Preparation}

The porous concrete pavement (PCP) consisted with 7 layers, i.e. surface layer, base layer, subbase layer, coarse sand filter layer, fine sand filter layer and two layers of Geotextile. The PCP model was designed as per AASHTO, 1993 [11] guideline and followed typical layer thickness used for porous concrete pavements [10]. In this study, we used thickness of 4", 8", 8", 4" and 6" for surface layer, base layer, sub-base layer, coarse sand layer and fine sand layer respectively (Figure 1). The model of porous concrete pavement had a cross-section of $2 \mathrm{ft} \times 2 \mathrm{ft}$ and a height of $2.5 \mathrm{ft}$.

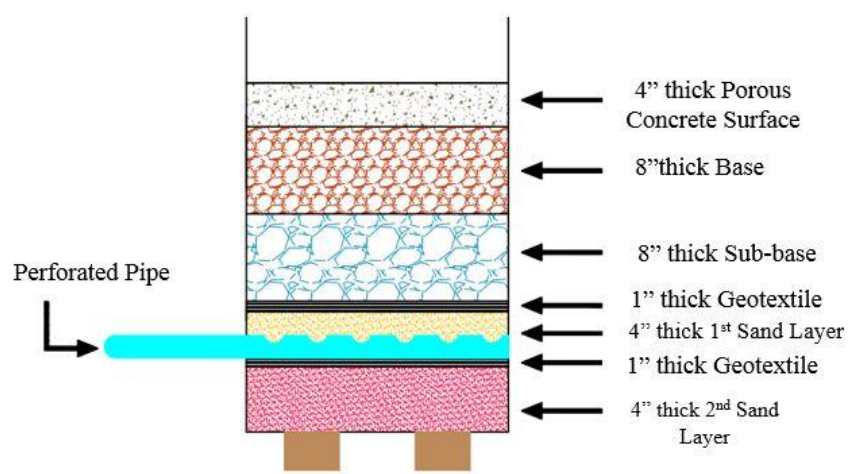

(a)

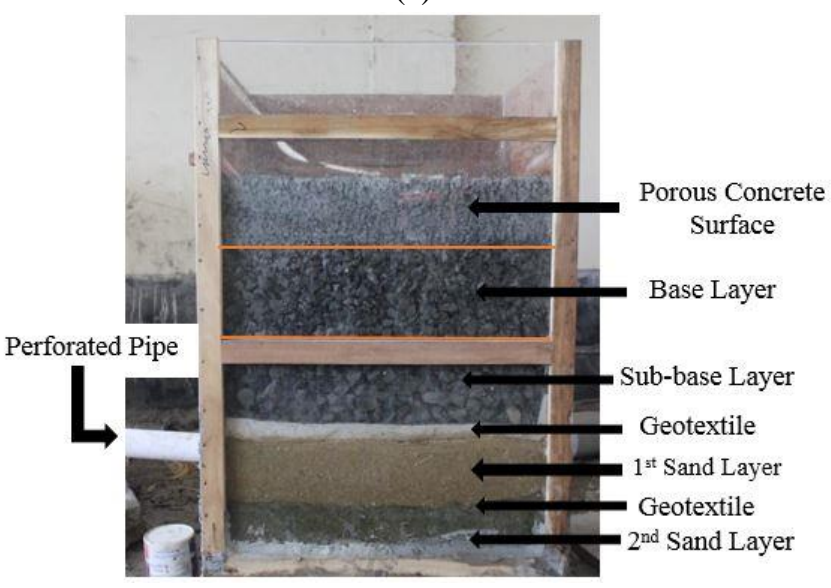

(b)

Figure 1: Porous Concrete Pavement in

(a) Schematic View and (b) Model

\subsubsection{Surface Layer}

This layer consists of porous concrete. The proportion of the mixture is (cement) 1: (coarse aggregate) 4 . This ratio is optimum for porosity and permeability [12]. In this study, we used gradation of aggregate shown in Table 1. Usually, the water cement $(\mathrm{w} / \mathrm{c})$ ratios between $0.27-0.30$ are used with admixtures [13].

Table 1: Gradation of Aggregate of Porous Concrete Mix

\begin{tabular}{ccc}
\hline $\begin{array}{c}\text { Sieve No. } \\
(\mathrm{mm})\end{array}$ & $\begin{array}{c}\text { Weight } \\
(\mathrm{gm})\end{array}$ & \% Weight \\
\hline 12.5 & 9 & 0.45 \\
9.5 & 93 & 4.65 \\
4.75 & 1671 & 83.55 \\
2.36 & 223 & 11.15 \\
1.18 & 3 & 0.15 \\
Pan & 1 & - \\
Total & 2000 & \\
\hline
\end{tabular}


Kalimur Rahman et al., J. Mod. Mater.; Vol. 7, Issue 1, pp: 37-44, 2020

\subsubsection{Base and Sub-base Layer}

In this study, open-graded aggregate used as a base. We used aggregate sizes from $19 \mathrm{~mm}$ $(20 \mathrm{~mm})$ to $9.375 \mathrm{~mm}(10 \mathrm{~mm})$. A single sub-base layer was used in this study. A coarse layer used which comprised of smaller sized aggregate above the sub-base and sand filter layers used for water quality improvement. We used aggregate sizes from $19 \mathrm{~mm}$ to $38 \mathrm{~mm}$.

\subsubsection{Sand Filter Layer}

In the study, we used two sand filters below the sub-base. One sand filter used as coarse sand and another is fine sand. $1^{\text {st }}$ sand filter used as coarse sand and $2^{\text {nd }}$ sand filter as fine sand. Natural sand was used for cushion layer. The fineness modulus (FM) of the coarse sand and fine sand are 2.56 and 1.67 respectively. The $1^{\text {st }}$ sand and $2^{\text {nd }}$ sand filters in square model were packed in layer 4" and 6" thickness respectively with preparatory tamping and was not in the state of fully compacted.

\subsubsection{Geotextile Layer}

A geotextile layer increases the pollutant attenuation capabilities [14], reduces the heavy metal, suspended solids and enhance fine particle retention capacity $[6,15,16]$ within the porous concrete pavement system. In this study, plastic geotextile was set in two layers, one between subbase and coarse sand layer and another one between coarse sand and fine sand layer. Plastic geotextile consist of $2 \%$ black carbon, which help to removal of heavy metal.

\subsection{Porosity and Permeability Test for Surface Layer}

\subsubsection{Porosity Test}

The effectiveness of porous concrete are determined by volumetric method [8]. In this method, a cylindrical test specimen is used where, a mass of water to fill a sealed test is compared with an equivalent volume of void to measure the porosity. The effective porosity is calculated by the Equation 1:

$$
P=\left[\frac{M_{1}-M_{2}}{\rho_{w} V}\right] \times 100
$$

Where, $P=$ Total porosity of the test specimen $(\%), M_{1}=$ Weight of the test specimen air-dried for 24 hours (gm), $M_{2}=$ Weight of the test specimen submerged in water (gm), $V=$ Volume of the test specimen $\left(\mathrm{cm}^{3}\right)$ and $\rho_{w}=$ Density of water $\left(\mathrm{gm} / \mathrm{cm}^{3}\right)$

The porosity of porous concrete within 15\%$30 \%$ are acceptable usually $[17,18]$. In this study, the porosity value is $27.2 \%$, which is in the acceptable range.

\subsubsection{Permeability Test}

Permeability defines the flow of water through the material structure. Concrete mixture proportioning have influence on porosity and permeability of porous concrete [19]. Permeability test of PCP in this study have been conducted by constant head permeability method $[20,21]$. The coefficient of permeability $\mathrm{k}$ as given:

$$
k=\frac{Q L}{A h t}
$$

Where, $k=$ Coefficient of permeability $(\mathrm{cm} / \mathrm{s})$, $Q=$ Quantity of flow through the test specimen $\left(\mathrm{cm}^{3}\right), L=$ Specimen length $(\mathrm{cm}), A=$ Cross sectional area of the test specimens $\left(\mathrm{cm}^{2}\right), b=$ Water head $(\mathrm{cm})$ and $t=$ Time $(\mathrm{s})$

The porous mixtures had permeability values between 1 to $2 \mathrm{~cm} / \mathrm{s}$, which is recommended to be used as a drainage layer of pavement system [19]. In this study, the co-efficient of permeability is $1.83 \mathrm{~cm} / \mathrm{s}$, which is acceptable for good drainage.

\subsection{Rainfall Data Analysis}

We collected last 5-years rainfall data from a rain gauge station at Dhaka city from Bangladesh Metrological Department (BMD). The average total rainfall for a year is $1910.8 \mathrm{~mm}$. In this study, we were experiment for $100 \mathrm{~mm} /$ hour $(5 \%$ of 1910.8) rainfall intensity.

\subsection{Stormwater Quality Test}

Porous pavements can reduce pollutant loads by filtering, chemical degradation, adsorption and biological activity [8]. Copper $(\mathrm{Cu})$ is found in 
surface water, groundwater, seawater, Zinc ( $\mathrm{Zn}$ ) is an essential mineral that is naturally present in some foods and available as a dietary supplement. Lead $(\mathrm{Pb})$ is a heavy metal that is denser than most common materials. Nickel (Ni) is generally considered to be one of the most toxic metal found in environment. Higher concentration of $\mathrm{Ni}$ is harmful for human body. It causes cancer of lungs, nose and bone.

\subsubsection{Synthetic Stormwater Preparation}

In this study, we prepared synthetic stormwater in the laboratory. We analysis $\mathrm{Pb}, \mathrm{Cu}, \mathrm{Ni}$ and $\mathrm{Zn}$ these heavy metals which exist in stormwater. We took standard solutions of $\mathrm{Cu}, \mathrm{Pb}, \mathrm{Ni}$ and $\mathrm{Zn}$. The standard solution was added within 35 liters tap water. Then was well mixed using stirrer. After proper mixed, was collected some amount of sample for testing in laboratory. After testing we have been knowing about correct concentration of $\mathrm{Cu}, \mathrm{Pb}, \mathrm{Ni}$ and $\mathrm{Zn}$. Finally, synthetic stormwater is prepared for experiment.

\subsection{Experiment Procedure}

Experimental setup of the porous concrete pavement is shown in Fig. 2. Total synthetic stormwater tank was placed beside the pavement, which above of the pavement surface. A water pipe connected one end with the tank and another end with shower. The water flow through the pipe average 2.7 liter/min. The water infiltrated through the pavement, then we collected sample from two points. 1st point located at 24" below the porous concrete pavement surface and 2nd point located at 30" below the porous concrete pavement surface, which shown the Fig. 2. The water samples were collected at 3 minutes, 6 minutes, 11 minutes and 16 minutes from the start of the test session from each point. The tank was empty within 13 minutes. Label of the collected 8 samples with respect to the time represented in the Table 2 . The collection time $3 \mathrm{~min}, 6 \mathrm{~min}, 11 \mathrm{~min}$ and 16 min corresponding to 1 st collection point (2nd collection point) were labeled as 1-1 (2-1), 1-2 (22), 1-3 (2-3) and 1-4 (2-4) respectively. The volume of each sample was about $500 \mathrm{ml}$.

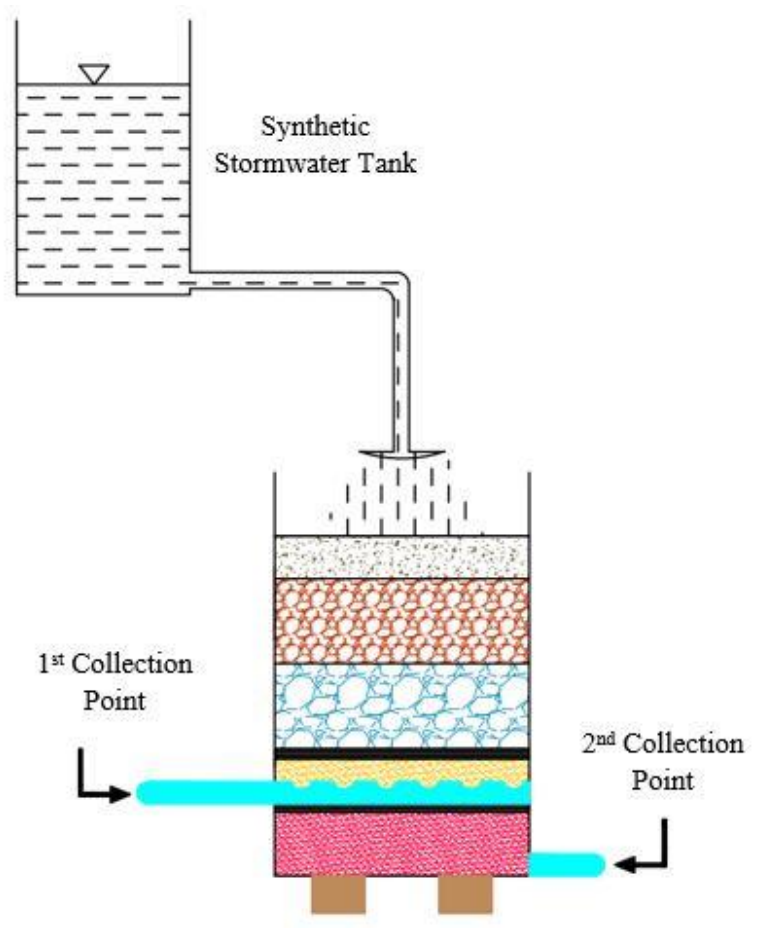

Figure 2: Schematic View of Experimental Setup in this Study

Table 2: Test results of heavy metal concentration at different layers of the porous concrete pavement at various sampling time

\begin{tabular}{|c|c|c|c|c|c|}
\hline \multicolumn{2}{|c|}{ Test Parameter } & \multirow{2}{*}{$\begin{array}{c}\mathrm{Cu} \\
(\mathrm{ppm})\end{array}$} & \multirow{2}{*}{$\begin{array}{c}\mathrm{Pb} \\
(\mathrm{ppm})\end{array}$} & \multirow{2}{*}{$\begin{array}{c}\begin{array}{c}\mathrm{Ni} \\
(\mathrm{ppm})\end{array} \\
0.2136\end{array}$} & \multirow{2}{*}{$\begin{array}{c}\begin{array}{c}\mathrm{Zn} \\
(\mathrm{ppm})\end{array} \\
0.0152\end{array}$} \\
\hline Initial & & & & & \\
\hline \multirow{5}{*}{$\begin{array}{l}\text { At } 1^{\text {st }} \\
\text { Collection } \\
\text { Point }\end{array}$} & $3 \mathrm{~min}$ & 0.2119 & 0.3851 & 0.2121 & 0.0019 \\
\hline & $6 \mathrm{~min}$. & 0.2112 & 0.2785 & 0.1921 & 0.0015 \\
\hline & $11 \mathrm{~min}$. & 0.1168 & 0.2763 & 0.1713 & 0.0012 \\
\hline & $16 \min$. & 0.0953 & 0.1751 & 0.1711 & 0.0011 \\
\hline & $3 \mathrm{~min}$. & 0.0923 & 0.2015 & 0.1151 & 0 \\
\hline \multirow{3}{*}{$\begin{array}{l}\text { At } 2^{\text {nd }} \\
\text { Collection } \\
\text { Point }\end{array}$} & $6 \mathrm{~min}$ & 0.0781 & 0.2003 & 0.0983 & 0 \\
\hline & $11 \mathrm{~min}$. & 0.0315 & 0.1963 & 0 & 0 \\
\hline & 16 min. & 0.0181 & 0.0561 & 0 & 0 \\
\hline
\end{tabular}

\subsection{Heavy Metals Test Results in Laboratory}

Heavy metals (Copper, Lead, Nickel and Zinc) were analyzed by atomic absorption Spectrophotometer (AAS). For digesting, $2.5 \mathrm{ml}$ diluted $\mathrm{HNO}_{3}$ acid (1:3) and $7.5 \mathrm{ml}$ diluted $\mathrm{HCl}$ acid (1:3) were added to $100 \mathrm{ml}$ of synthetic stormwater sample. Then, the acidified samples were kept overnight. The digested for two hours under reflux conditions. After the cooled samples were filtered and the filtrate volume was adjusted 
to $100 \mathrm{ml}$ by de-ionized water. The sample was then ready for analysis through the Atomic Absorption Spectrophotometer (AAS) Model AA-7000. The Test results of the heavy metals $\mathrm{Cu}, \mathrm{Pb}, \mathrm{Ni}$ and $\mathrm{Zn}$ concentration are summarized in Table 2.

\section{Discussion}

\subsection{Heavy metals in synthetic stormwater}

The maximum amount of $\mathrm{Cu}$ concentration has reduced by the sand layers and geotextile layers (Figure 3a). The amount of decrease of $\mathrm{Cu}$ concentration not varies on using of the coarse sand layer or fine sand layer. The maximum amount of $\mathrm{Pb}$ concentration has reduced by the coarse sand layers and geotextile layers. Also, $\mathrm{Pb}$ was removed by the fine sand layer but it is relatively low (Figure 3b).

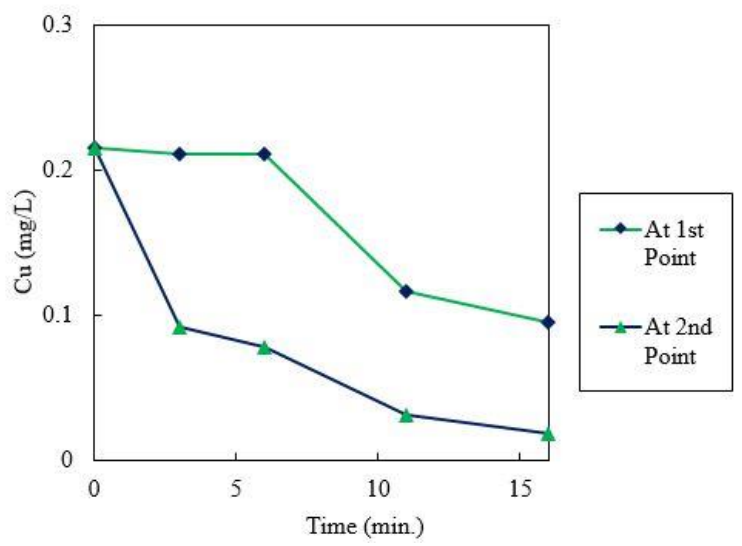

(a)

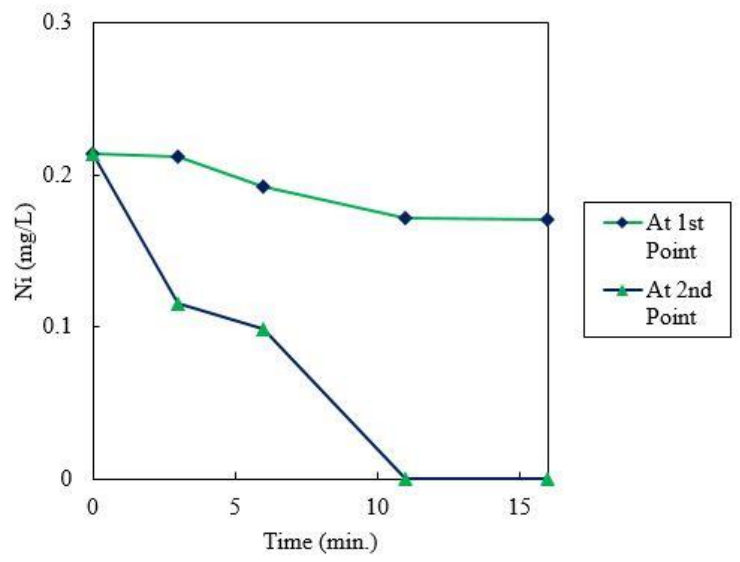

(b)

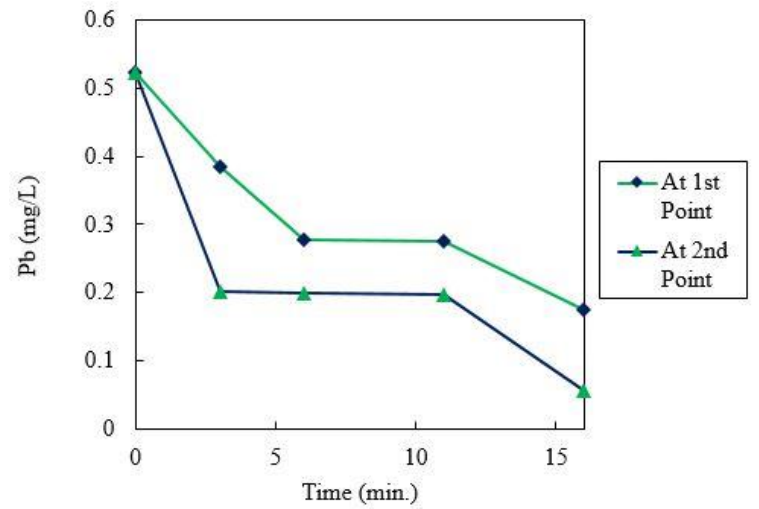

(c)

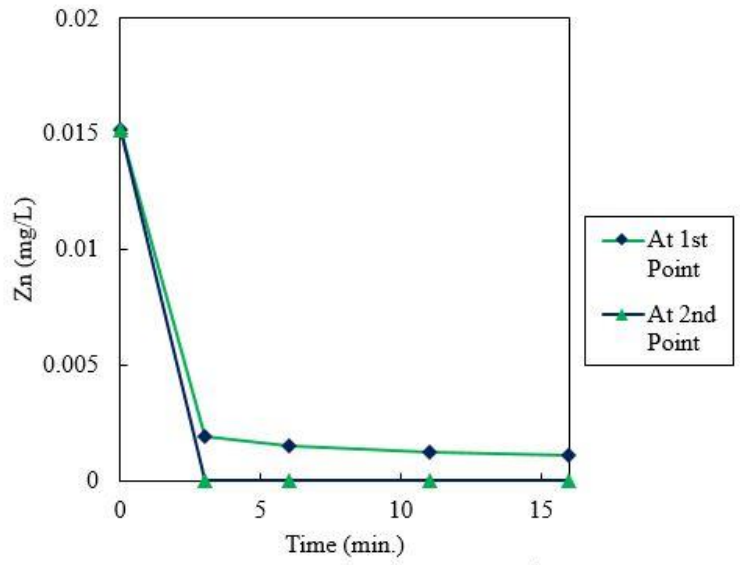

(d)

Figure 3: Concentration of (a) $\mathrm{Cu}$, (b) $\mathrm{Pb}$, (c) $\mathrm{Ni}$ and (d) $\mathrm{Zn}$ with respect to the time at $1^{\text {st }}$ collection point and at $2^{\text {nd }}$ collection point

Less amount of $\mathrm{Ni}$ concentration reduced by the coarse sand layer (Figure 3c). Relatively, maximum amount of $\mathrm{Ni}$ concentration has reduced by using of fine sand layer. In synthetic stormwater, initial $\mathrm{Zn}$ concentration was 0.0152 ppm. Zn concentration gradually reduced in synthetic stormwater with time. Total concentration has removed by the two sand layers and geotextile layer, which consist of one coarse sand layer and another is fine sand layer (Figure 3d).

\subsection{Removal Analysis}

From the Table 3 we observed that, after 3 minutes maximum percentage of $\mathrm{Zn}$ concentration was removed in the 1 st collection point. But, other parameters were reduced very small amount. After 6 minutes, Pb concentration was removed about $50 \%$, but for removed about $50 \% \mathrm{Cu}$ concentration required time was 11 minutes. At the end of 16 minutes $\mathrm{Cu}, \mathrm{Pb}$ and $\mathrm{Zn}$ 
concentration were removed of $56 \%, 67 \%$ and 93\% respectively, but $\mathrm{Ni}$ concentration was removed only of $20 \%$ shown in Fig. 4(a).

Table 3: Percentage removal of $\mathrm{Cu}, \mathrm{Pb}, \mathrm{Ni}$ and $\mathrm{Zn}$ by the porous concrete pavement

\begin{tabular}{cccccc}
\hline $\begin{array}{c}\text { Collection } \\
\text { point }\end{array}$ & $\begin{array}{c}\text { Time } \\
(\mathrm{min} .)\end{array}$ & $\begin{array}{c}\mathrm{Cu} \\
(\%)\end{array}$ & $\begin{array}{c}\mathrm{Pb} \\
(\%)\end{array}$ & $\begin{array}{c}\mathrm{Ni} \\
(\%)\end{array}$ & $\begin{array}{c}\mathrm{Zn} \\
(\%)\end{array}$ \\
\hline $1^{\text {st }}$ & 3 & 2 & 26 & 1 & 88 \\
& 6 & 2 & 47 & 10 & 90 \\
& 11 & 46 & 47 & 20 & 92 \\
& 16 & 56 & 67 & 20 & 93 \\
$2^{\text {nd }}$ & 3 & 57 & 61 & 46 & 100 \\
& 6 & 64 & 62 & 54 & 100 \\
& 11 & 85 & 62 & 100 & 100 \\
& 16 & 92 & 89 & 100 & 100 \\
\hline
\end{tabular}

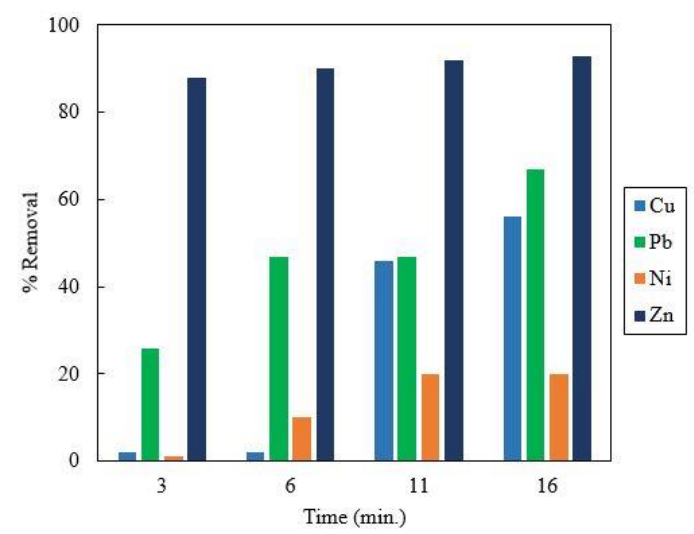

(a)

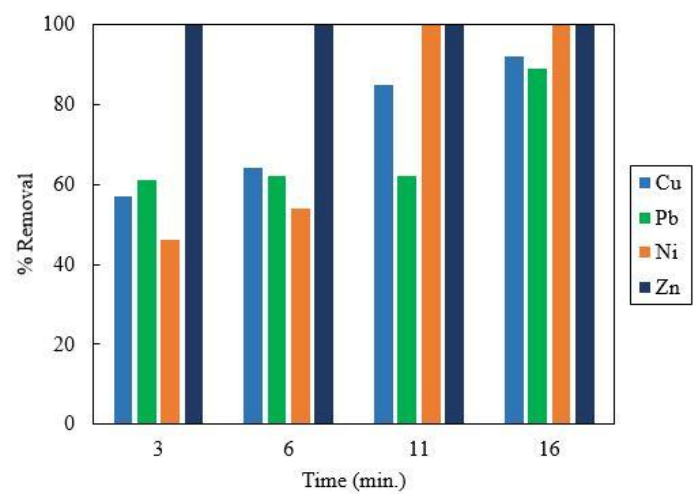

(b)

Figure 4: Percentage (\%) removal of $\mathrm{Cu}, \mathrm{Pb}, \mathrm{Ni}$ and $\mathrm{Zn}$ with respect to the time at (a) $1^{\text {st }}$ collection point and (b) $2^{\text {nd }}$ collection point

From the Table 3 we observed that, after 3 minutes Zinc $(\mathrm{Zn})$ concentration was removed $100 \%$ in the $2^{\text {nd }}$ collection point. But other three parameters were gradually reduced with respect to time. For removed of $100 \%$ Nickel (Ni) concentration required time was 11 minutes. At the end of 16 minutes $\mathrm{Cu}$ and $\mathrm{Pb}$ concentration were removed of $92 \%$ and $89 \%$ respectively, shown in Figure 4(b).

When water pass through the 4-inch porous concrete pavement layer, 8-inch porous base layer, 8-inch porous sub-base layer, 4-inch coarse sand layer and 1-inch geotextile layer, then Copper and Lead concentration has removed of $56 \%$ and $67 \%$ respectively. But when water passes through another 6-inch fine sand layer and 1-inch geotextile, then $\mathrm{Cu}$ and $\mathrm{Pb}$ concentration has removed of $92 \%$ and $89 \%$ respectively shown in Figure 5.

When water pass through the 4-inch porous concrete pavement layer, 8-inch porous base layer, 8-inch porous sub-base layer, 4 -inch coarse sand layer and 1-inch geotextile layer, then Nickel and Zinc concentration has removed of $20 \%$ and $93 \%$ respectively. But when water passes through another 6-inch fine sand layer and 1-inch geotextile, then $\mathrm{Ni}$ and $\mathrm{Zn}$ concentration has removed of $100 \%$ shown in Figure 5.

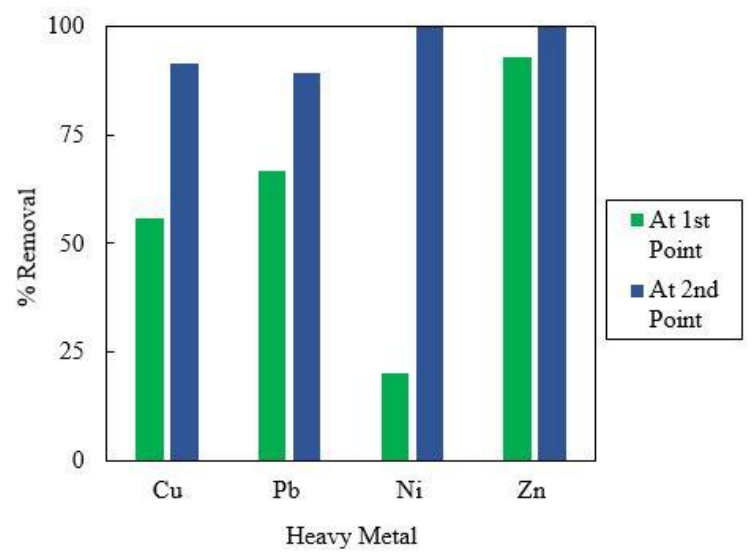

Figure 5: Percentage (\%) removal of heavy metal

The results showed that the average removal efficiency of $\mathrm{Ni}$ concentration is higher by the fine sand layer. The average removal efficiency of $\mathrm{Zn}$ concentration is maximum by the coarse sand layer. Removal efficiency of $\mathrm{Zn}$ concentration is $100 \%$ from first time to last time.

Legret et al. [15] used $6 \mathrm{~cm}$ porous asphalt, two $10 \mathrm{~cm}$ porous asphalt stabilized graded aggregates, $35 \mathrm{~cm}$ thickness of crushed materials and woven geotextile laid on the formation level 
Kalimur Rahman et al., J. Mod. Mater;; Vol. 7, Issue 1, pp: 37-44, 2020

and found reductions of $79 \%$ and $72 \%$ for Lead and $\mathrm{Zn}$ respectively during three-month runoff on the surface. Hogland and Niemczynowicz [23] found $62 \%$ reduction of zinc, $42 \%$ reduction of copper, $50 \%$ reduction of lead for a porous pavement system receiving snowmelt runoff. Some prior studies used porous reactive concrete [24] and geo-polymer with PCP [1] to remove heavy metal from stormwater. In this study, we have used locally available materials, which are low cost and removal efficiency of $\mathrm{Zn}, \mathrm{Pb}$ and $\mathrm{Cu}$ are higher than some prior studies [15, 23]. Therefore, our proposed lab scale PCP model can be experimented for the future practical application in the field.

\section{Conclusions}

This study evaluated the porous concrete pavement structures in order to assess their capability to reduce the concentration of heavy metals from stormwater. Synthetic stormwater quality analyses, after the passage through the model, by coarse sand layer and geotextile layer are reduced the concentration of $\mathrm{Cu}, \mathrm{Pb}$ and $\mathrm{Zn}$ are $56 \%, 67 \%$ and $93 \%$ respectively, but reduce $\mathrm{Ni}$ concentration $20 \%$. Since the atomic mass of $\mathrm{Ni}$ is relatively less than $\mathrm{Cu}, \mathrm{Zn}$ and $\mathrm{Pb}$. So, the atomic crystal size of $\mathrm{Ni}$ is less. When fine sand layer and geotextile layer are added below the coarse sand layer, then $100 \%$ reduced the concentration of $\mathrm{Zn}$ and $\mathrm{Ni}$, also about $90 \%$ reduced the concentration of $\mathrm{Cu}$ and $\mathrm{Pb}$. Coarse and fine sand layers can remove the heavy metal, because of it have maximum adsorption capacity. The plastic geotextile can remove the heavy metal, because of it consist of black carbon. So the pavement improved stormwater quality by removing heavy metals. This infiltrated stormwater can use as groundwater recharger or water treatment plant. This research work has opened up new possibilities for further works to improve the metal removal efficiency of PCP. Additional studies are required to observe clogging effect of porous concrete pavement. Further study can determine efficiency after long time flow on the pavement. The study can be extended for recycling materials, determine efficiency at various metal concentration stormwater and considering various water cement ratio.

\section{Declarations}

\subsection{Acknowledgements}

The authors would like to acknowledge Department of Civil Engineering, Dhaka University of Engineering and Technology (DUET) for providing funds to conduct this research.

\subsection{Competing Interests}

There is no potential conflict of interest exists in this publication.

\section{How to Cite this Article:}

K. Rahman, S. Barua, M. S. Anwar, M. Z. Hasan, and S. Islam, "Removal of Heavy Metals from Stormwater Using Porous Concrete Pavement", J. Mod. Mater., vol. 7, no. 1, pp. 37-44, Jul. 2020. doi:10.21467/jmm.7.1.37-44

\section{References}

[1] M. Turco., G. Brunetti, S.A. Palermo, G. Capano, G. Grossi, M. Maiolo and P. Piro, "On the environmental benefits of a permeable pavement: metals potential removal efficiency and Life Cycle Assessment", Urban Water Journal, pp.1-9, 2020.

[2] D. K. Hein, "Development of an Asce Standard for Permeable Interlocking Concrete Pavement," Of the 2014 Conference of the Transportation Association of Canada Montréal, Québec, Vol. 416, pp. 1-15, 2014.

[3] N. Delatte, D. Miller and A. Mrkajic, "Portland cement pervious concrete pavement: Field performance investigation on parking lot and roadway pavements", RMC Research \& Education Foundation, pp. 76. 2007. Retrieved

from http://trid.trb.org/view.aspx ?id=1152804

[4] R. Reza and G. Singh, "Heavy metal contamination and its indexing approach for river water", International Journal of Environmental Science and Technology, Vol. 7, No. 4, pp. 785-792, 2010. https://doi.org/10.1007/BF03326187

[5] ACI, "Building Code Requirements for Structural Concrete", In American Concrete Institute, Vol. 2007, 2011. https://doi.org/10.1016/0262-5075(85)90032-6

[6] H. M. Imran, S. Akib and M. R. Karim, "Permeable pavement and stormwater management systems: A review", Environmental Technology (United Kingdom), Vol. 34, No. 18, pp. 2649-2656, 2013. https://doi.org/10.1080/09593330.2013.782573

[7] M. Scholz and P. Grabowiecki, "Review of permeable pavement systems", Building and Environment, Vol. 42, No. 11, pp. 3830-3836, 2007. https://doi.org/10.1016/j.buildenv.2006.11.016

[8] W. Martin, M. Sumanasooriya, N. B. Kaye and B. Putman, "Design of Porous Pavements for Improved Water Quality and Reduced Runoff', Handbook of Environmental Engineering, 2018. pp. 425-451. https://doi.org/10.1002/9781119304418.ch14 
[9] E. Teymouri, S.F. Mousavi, H. Karami, S. Farzin and M.H. Kheirabad, "Municipal Wastewater pretreatment using porous concrete containing fine-grained mineral adsorbents", Journal of Water Process Engineering, Vol. 36, p.101346, 2020.

[10] X. Chen, Z. Niu, H. Zhang, Y. Guo, M. Liu and M. Zhou, "Study on the metakaolin-based geopolymer pervious concrete (MKGPC) and its removal capability of heavy metal ions", International Journal of Pavement Engineering, pp.1-12, 2019.

[11] AASHTO, "AASHTO Guide for Design of Pavement Structures", In AASHTO, 1993.

[12] R. Mahalingam and S. V. Mahalingam, "Analysis of pervious concrete properties", Gradjevinar, Vol. 68, No. 6, pp. 493-501, 2016 https://doi.org/10.14256/JCE.1434.2015

[13] T.D. Bhavana, S. Koushik, U. M. Kumar and R. Srinath, "Pervious concrete pavement", In International Journal of Civil Engineering and Technology, Vol. 8, 2017. https://doi.org/10.3141/2113-02

[14] S. J. Coupe, H. G. Smith, A. P. Newman and Puehmeier, T., "Biodegradation and microbial diversity within permeable pavements", European Journal of Protistology, 2003. https://doi.org/10.1078/0932-473900027

[15] K. Tota-maharaj, P. Grabowiecki and A. Babatunde, "The Performance and Effectiveness of Geotextiles Within Permeable Pavements for Treating Concentrated Stormwater", Sixteenth International Water Technology Conference, IWTC 16 2012, Istanbul, Turkey, pp. 1-13, 2012.

[16] M. Legret, V. Colandini and C. Le Marc, "Effects of a porous pavement with reservoir structure on the quality of runoff water and soil", Science of the Total Environment, Vol. 189-190, pp. 335-340, 1996. https://doi.org/10.1016/0048-9697(96)05228-X

[17] N. Neithalath, J. Weiss and J. Olek, "Characterizing Enhanced Porosity Concrete using electrical impedance to predict acoustic and hydraulic performance", Cement and Concrete Research, 2016. https://doi.org/10.1016/j.cemconres.2006.09.001

[18] NRCA and National ready mixed concrete association (NRMCA), CIP 38 - Pervious Concrete. Concrete in Practice. What, Why and How? Vol. 3, 2004.

[19] F. Montes and L. Haselbach, "Measuring hydraulic conductivity in pervious concrete", Environmental Engineering Science, Vol. 23, No. 6, pp. 960-969, 2006. https://doi.org/10.1089/ees.2006.23.960

[20] A. Cheng, H. M. Hsu, S. J. Chao and K. L. Lin, "Experimental study on properties of pervious concrete made with recycled aggregate", International Journal of Pavement Research and Technology, Vol. 4, No. 2, pp. 104, 2011. https://doi.org/10.6135/ijprt.org.tw/2011.

[21] B. Huang, L. N. Mohammad, A. Raghavendra and C. Abadie, "Fundamentals of permeability in asphalt mixtures", Proceedings of the Association of Asphalt Paving Technologists, 1999.

[22] B. Huang, H. Wu, X. Shu and E. G. Burdette, "Laboratory evaluation of permeability and strength of polymer-modified pervious concrete", Construction and Building Materials, Vol. 24, No. 5, pp. 818-823, 2010.

https://doi.org/10.1016/j.conbuildmat.2009.10.025

[23] W. Hogland and J. Niemczynowicz, "The unit superstructure - a new construction to prevent groundwater depletion", Conjunctive Water Use. Proc.
Budapest Symposium, (January 1986), pp. 513-522, 1986.

[24] R.R. Holmes, M.L. Hart and J.T. Kevern, "Removal and breakthrough of lead, cadmium, and zinc in permeable reactive concrete", Environmental Engineering Science, Vol. 35, No. 5, pp.408-419, 2018.

Publish your research article in AIJR journals-

* Online Submission and Tracking

* Peer-Reviewed

* Rapid decision

* Immediate Publication after acceptance

* Articles freely available online

* Retain full copyright of your article.

Submit your article at journals.aijr.in

Publish your books with AIJR publisher-

* Publish with ISBN and DOI.

* Publish Thesis/Dissertation as Monograph.

* Publish Book Monograph.

* Publish Edited Volume/ Book.

* Publish Conference Proceedings

* Retain full copyright of your books.

Submit your manuscript at books.aijr.org 